\title{
Endogenous cytokinins dynamics during development of sporophytes of perennial ferns Dryopteris filix-mas and Polystichum aculeatum (Dryopteridaceae)
}

\author{
Nina P. VEDENICHEVA, Iryna V. KOSAKIVSKA \\ M.G. Kholodny Institute of Botany, National Academy of Sciences of Ukraine \\ 2 Tereshchenkivska Str., Kyiv 01004, Ukraine \\ vedenicheva@ukr.net
}

Vedenicheva N.P., Kosakivska I.V. Endogenous cytokinins dynamics during development of sporophytes of perennial ferns Dryopteris filix-mas and Polystichum aculeatum (Dryopteridaceae). Ukr. Bot. J., 2018, 75(4): 384-391.

\begin{abstract}
The qualitative composition and dynamics of cytokinins in the fronds and rhizomes of perennial ferns Dryopteris filix-mas and Polystichum aculeatum have been investigated using high-performance liquid chromatography in combination with mass spectrometry. Sporophytes were studied at the stages of intensive vegetative growth (April), formation of sporangia (May) and sporulation (June). Plants of P. aculeatum were also analyzed at the stage of winter vegetation (February). The accumulation of trans-zeatin in fronds of $P$. aculeatum was revealed at the intensive growth stage, whereas in $D$. filixmas, the increase in this cytokinin content was observed during the formation of sporangia. The level of zeatin riboside increased in fronds and rhizomes of both fern species at the stage of sporulation. The cessation of the ferns intensive growth involved the accumulation of conjugate - zeatin- $O$-glucoside. At certain stages of sporophyte development, isopentenyl-type cytokinins were detected: in D. filix-mas, low levels of isopentenyladenine - during sporulation, and in $P$. aculeatum, quite significant amounts of isopentenyladenosine and isopentenyladenine - in fronds at the stage of intensive growth and in rhizomes - during sporangia formation. In $P$. aculeatum fronds, active free cytokinins - zeatin and zeatin riboside - were accumulated during the winter vegetation indicating that they were involved in the maintenance of the plant photosynthetic activity under unfavorable conditions. The root system of both fern species was characterized by a lower level of cytokinins as compared to the aerial part. The dynamics of the spectrum and content of cytokinins in the fern organs was species-specific and indirectly testified to the involvement of these phytohormones in growth and development control. The features of differences and similarities of the regulatory role of cytokinins in ferns and seed plants are discussed.
\end{abstract}

Keywords: Polystichum aculeatum, Dryopteris filix-mas, cytokinins, fern, growth, development

\section{Introduction}

The sequence of the morpho- and ontogenesis stages, integration of the growth activity of individual organs into a coherent coordinated system, balancing of donor-acceptor relationships, realization of reproduction, communication with the environment all these complex processes that ensure the plant vital functions are controlled by the hormonal system, one of the components of which is cytokinins. The class of cytokinins includes derivatives of adenine, the compounds that are similar in structure, but have different biological activity and unequal functions. Hormone molecules with certain variations in the structure of the side chain are likely to mediate different biological signals (Romanov, 2009). All current models and schemes that describe the mechanism of cytokinins action are based mainly on the results of experiments with higher flowering plants, chiefly Arabidopsis (Kieber,

(C) N.P. VEDENICHEVA, I.V. KOSAKIVSKA, 2018
Schaller, 2014; Zürcher, Müller, 2016). However, studies on plants of different systematic position have shown that the pattern of metabolism, reception and transduction of cytokinin signals are species-specific, and study of their localization, dynamics, influence of exogenous hormones and transport also pointed to the organ-specificity and ability to direct differently both development of various tissues and information exchange between the plant underground and aerial parts (Vedenicheva, 2016). Thus, the extrapolation of existing generalizations to various plant objects may be quite ambiguous. This is especially true for plants that are at lower levels of evolutionary development, in particular, vascular cryptogams. The major and most widespread group among the latter is Polypodiophyta. Although ferns represent the closest sister group to seed plants (Pryer et al., 2001) and the comparison of these two groups can provide important information concerning the mechanisms of formation and further 
evolution of the hormonal system, there is very little data on the phytohormones occurrence and functioning in ferns. Studies on the cytokinins involvement in the development of these plants are mainly focused on the effects of exogenous hormones on growth in culture (Kosakivska et al., 2016). The addition of cytokinin along with other phytohormones to the culture medium was found to contribute to the regeneration of Asplenium nidus L. sporophyte, while gametophyte developed without any addition of growth substances (Menéndez et al., 2011). During cultivation of Osmunda regalis L. ferns, the morphology and sexual development of gametophytes depended on the concentration of kinetin (Greer et al., 2012). Sub-nanomolar concentrations of BAP, kinetin and isopentenyladenine altered the rate of growth, division, elongation and differentiation of Ceratopteris richardii Brongn cells (Spiro et al., 2004). Cytokinins, together with auxins and gibberellins, accelerated apogamy in regenerated gametophytes of the fern Dryopteris affinis subsp. affinis (Rivera et al., 2018). $\mathrm{BAP}$, zeatin riboside and isopentenyladenine did not affect the formation of new nodes and the stem growth of the water fern Marsilea quadrifolia L., whereas they inhibited the development of rhizome and this effect was proportional to the concentration and duration of treatment (Rolli et al., 2015). BAP addition into the culture medium had no effect on spores germination in the tree fern Alsophila odonelliana (Alston) Lehnert, but it significantly increased cell proliferation and resulted in the production of branched filaments (Bonomo et al., 2013). High BAP concentrations were inhibiting for spore germination and gametophytes development of Polystichum aculeatum (L.) Roth in vitro, whereas lower quantities had slight stimulating effect (Babenko et al., 2018). All these results clearly indicate that cytokinins, undoubtedly, can regulate ferns growth and development. However, it is known that phytohormones applied exogenously are metabolized faster than endogenous ones, and the hormone excess disturbs the hormonal balance and is often perceived by plants as stress (Vedenicheva, Kosakivska, 2017). Therefore, studying the qualitative composition and quantitative content of endogenous cytokinins in plant organs at different stages of growth and development, comparing these characteristics with the growth rate and morphological features are reguired for elucidation of the specific role of these hormones in a certain group of plants. Such information concerning vascular cryptogams is scarce. Differences in endogenous cytokinins levels in developing female and male gametophytes of the fern Blechnum spicant $\mathrm{L}$. were established (Menéndez et al., 2009). Previously, we have found that the distribution and dynamics of different cytokinins in the organs of the sporophytic and vegetative shoots of Equisetum arvense L. possess certain features that considerably distinguish these plants from angiosperms (Vedenicheva, Sytnik, 2013). At the same time, changes in the content of cytokinins in the organs of the hydrophyte fern Salvinia natans (L.) All. during vegetation indicated that the functions of these hormone isoforms are similar to those established in flowering plants (Vedenicheva, Kosakivska, 2016).

In order to understand the regulatory role of cytokinins in the fern growth processes and to reveal the general patterns of hormone functioning in different representatives of this plant group, we studied the endogenous cytokinins dynamics during sporophyte development in the perennial ferns Polystichum aculeatum (L.) Roth. and Dryopteris filix-mas (L.) Schott.

\section{Materials and methods}

Plants were collected in the Acad. O.V. Fomin Botanical Garden, Taras Shevchenko National University of Kyiv, starting from the end of April, at intervals of approximately one month. The dates for the plants analysis corresponded to the main phenological stages of development described earlier (Kotukhov, 1974; Vasheka, 2004): stage of intensive vegetative growth (April), stage of sporangia formation (May) and stage of sporulation (June). Polystichum aculeatum plants were analyzed additionally at the stage of winter vegetation (February). The fronds and rhizomes of sporophyte were separated and fixed in liquid nitrogen. Growth conditions (temperature regime, illumination, composition and soil acidity) were described in detail (Babenko et al., 2017).

For cytokinins analysis the samples $\left(\begin{array}{ll}10 & \mathrm{~g}\end{array}\right)$ were homogenized during 3 min using electrical homogenizer (Mechanika Precyzyjna, Poland) in $80 \%$ methanol solution at $+4{ }^{\circ} \mathrm{C}$. Cytokinins were extracted with $80 \%$ methanol $(10 \mathrm{ml} / \mathrm{g})$ and purified as follows: centrifugation $\rightarrow$ fractionation with n-butanol ( $1: 1 \mathrm{v} / \mathrm{v})$ $\rightarrow$ ion-exchange chromatography on Dowex 50Wx8 (Serva, Germany) $\rightarrow$ thin layer chromatography on Silicagel $60 \mathrm{~F}_{254}$ (Merk, Germany). Details of purification procedures were described earlier (Vedenicheva et al., 2016). Detection and quantification of cytokinins were performed using HPLC-MS system (Agilent 1200, USA). Solid samples were dissolved in $200 \mu$ of mobile 


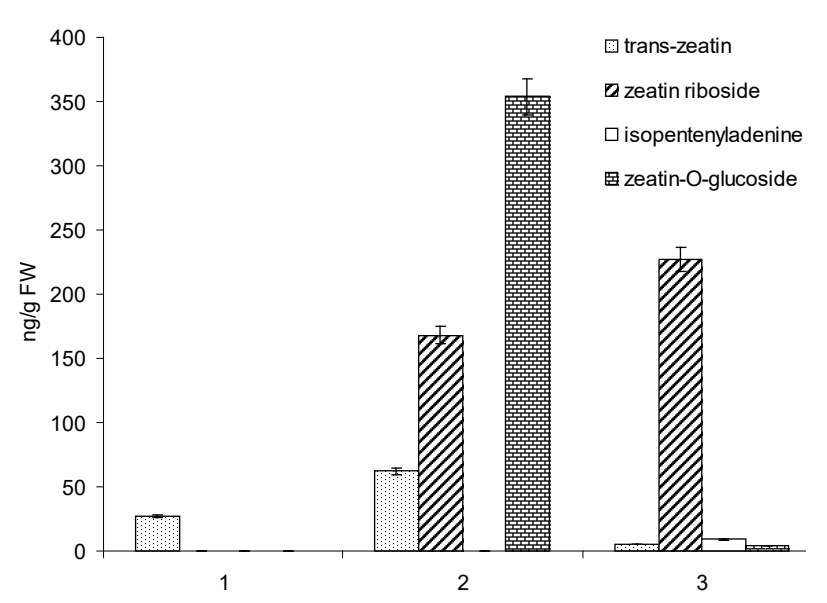

Fig. 1. Cytokinins content in fronds of the fern Dryopteris filix-mas at different stages of the sporophyte development: 1 - intensive vegetative growth stage, 2 - sporangia formation stage, 3 - spores maturation stage

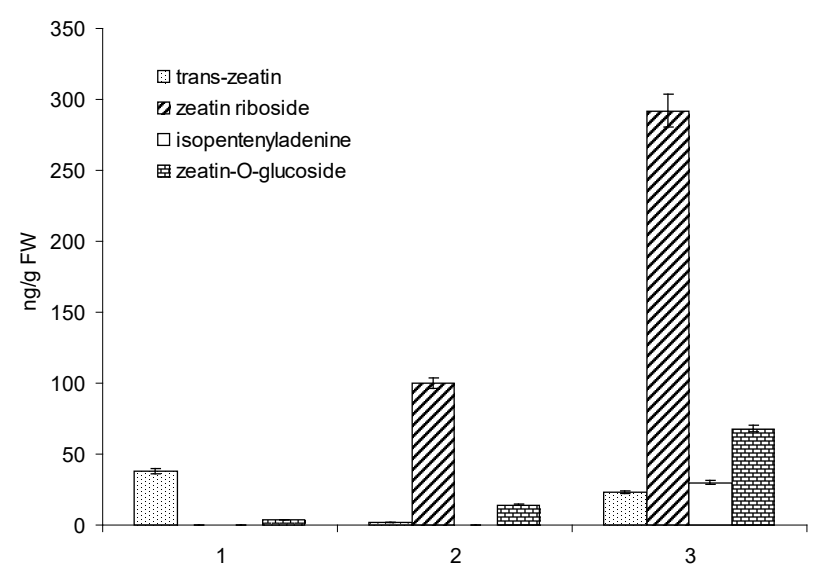

Fig. 2. Cytokinins content in rhizomes of the fern Dryopteris filix-mas at different stages of the sporophyte development: 1 - intensive vegetative growth stage, 2 - sporangia formation stage, 3 - spores maturation stage

phase and $5 \mu \mathrm{l}$ aliquot was injected into Agilent Zorbax Eclipse XDB-C18 column ( 4.6 x $250 \mathrm{~mm}, 5 \mu \mathrm{m})$. The column was eluted with an isocratic solvents system methanol : water : acetic acid $(37: 62.9: 0.1 \mathrm{v} / \mathrm{v} / \mathrm{v})$ at a flow rate of $0.5 \mathrm{ml} / \mathrm{min}$ and column temperature of $+30{ }^{\circ} \mathrm{C}$. The fractions eluted were directly passed through mass spectrometer (Agilent 6120 Quadrupole LC/MS) in a combined regime "multi mode" (electrospray and chemical ionization at atmosphere pressure) of positive ionization. Data were analyzed and processed using the software Agilent ChemStation, version B.03.01 on line. Concentrations were calculated on the basis of the peak areas for the endogenous compounds relative to those determined for the internal standards.

All experiments were conducted in three biological replicates. HPLC-MS analysis was carried out in five analytical replications. The data was processed according to the standard methods of variation statistics using Microsoft Excel 2007 program. Values of $\mathrm{P}<0,05$ were considered to be significant.

\section{Results and Discussion}

Dryopteris filix-mas fronds emerge as leaf rudiments in the form of a narrow ring at the rhizome apex and in this form they spend the first winter. On the second summer, they take a snail-like shape typical for all ferns, which is preserved for another season. Only in the third year, young leaves quickly expand and reach their full size. Investigations were started at the beginning of leaves deployment when they had not yet lost their snail-like shape. In this period, trans-zeatin was detected both in fronds and rhizomes (Fig. 1, 2). Its content was approximately the same in the plant aerial and underground part. Very small amounts of zeatin- $O$ glucoside were found in rhizomes.

When leaves deployment finished and they acquired final dimensions, vegetative growth significantly slowed down or stopped at all. At this time, there were clearly visible two rows of 5-8 sori on the reverse side of each leaf, located on the sides of the middle vein, in which spores formed (the second stage of the study). During this period, the content of trans-zeatin in fronds increased almost twice as compared to the previous stage of the analysis, significant amounts of zeatin riboside and zeatin- $O$-glucoside, previously absent (Fig. 1), were detected.

No trans-zeatin was found in the rhizome, where high levels of zeatin riboside occurred like in fronds and concentration of zeatin- $O$-glucoside increased.

At the end of the summer, microscopic spores ripened inside sporangia (the third stage of the study), later they dissipated and sprouted in heart-shaped gametophytes that will overwinter. The process of spores maturation involved some changes in the level of trans-zeatin in fronds and rhizomes in opposite directions: in fronds it decreased more than ten times, and in rhizomes it increased almost twenty times. The zeatin riboside concentration in the plant aerial and underground parts increased significantly and reached rather high values.

At this stage of $D$. filix-mas development, there was revealed isopentenyladenine, previously absent. In the rhizomes, its content exceeded three times that 
of fronds. The ratio of zeatin- $O$-glucoside and transzeatin levels in fronds and rhizomes was the same. This suggests that the metabolism of cytokinins in the plant tissues is aimed at the storage of excess hormones as a conjugate.

Development of $P$. aculeatum sporophytes at the first three phenological stages was similar morphologically to $D$. filix-mas. A much wider spectrum of cytokinins was detected in their fronds at the stage of intensive vegetative growth as compared to $D$. filix-mas. The content of active free cytokinins in this period was maximal (Fig. 3). Only trans-zeatin level was high in the rhizome (Fig. 4).

The concentration of trans-zeatin and zeatin riboside remained significant in $P$. aculeatum fronds during the transition to the reproductive development, whereas in rhizomes it somewhat decreased. In the sporophyte aerial and underground part, the conjugated form of zeatin accumulated. In addition, significant concentrations of isopentenyl-type cytokinins were found in the rhizome (Fig. 4).

During spores maturation, when the fern growth stopped, the content of active cytokinins decreased significantly, whereas the level of zeatin-O-glucoside enhanced (Fig. 3, 4). During winter vegetation, fronds retained a sufficiently high concentration of trans-zeatin while rhizomes had a high concentration of trans-zeatin and zeatin riboside (Fig. 3, 4).

The analysis of cytokinins in the organs of $D$. filixmas and $P$. aculeatum during vegetation showed that the sporophyte transition to various functional states is characterized by significant changes in the qualitative composition and quantitative content of these hormones, which testifies to their regulatory role in fern growth and development. Our findings indicate that during the sporophyte development the dynamics of individual components of the cytokinin pool was unambiguously species-specific. Thus, the vegetative growth of $D$. filixmas fronds is accompanied by a relatively low cytokinin content that is not typical for higher plants, whereas reproductive development appears to require significant amounts of hormones, especially zeatin riboside. The primary role of zeatin riboside in reproductive processes has previously been revealed both in angiosperms (Vedenicheva, Musatenko, 2008) and in vascular crytogams (Abul et al., 2010; Vedenicheva, Kosakivska, 2016). Polystichum aculeatum showed a high content of active cytokinins during vegetative growth that tended to decrease as that growth was gradually stopping. A similar pattern is characteristic for most seed plants,

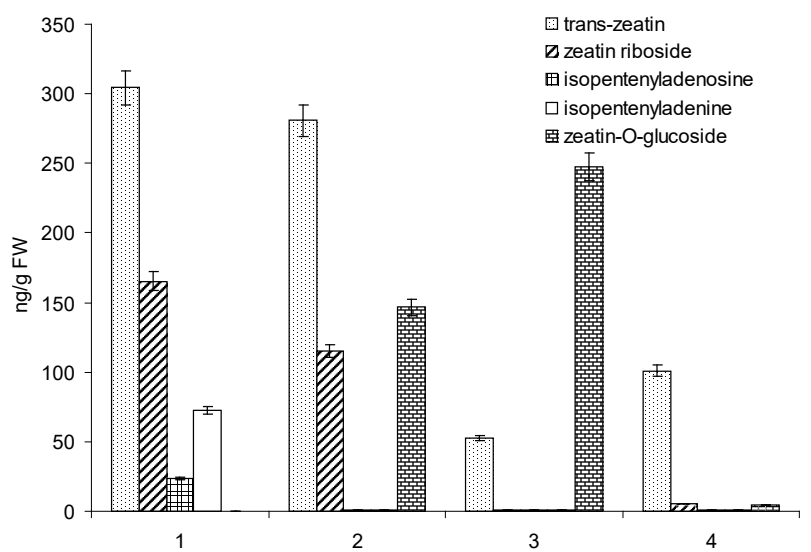

Fig. 3. Cytokinins content in fronds of the fern Polystichum aculeatum at different stages of the sporophyte development: 1 - stage of an intensive vegetative growth, 2 - stage of sporangia formation, 3 - stage of sporulation, $4-$ stage of winter vegetation

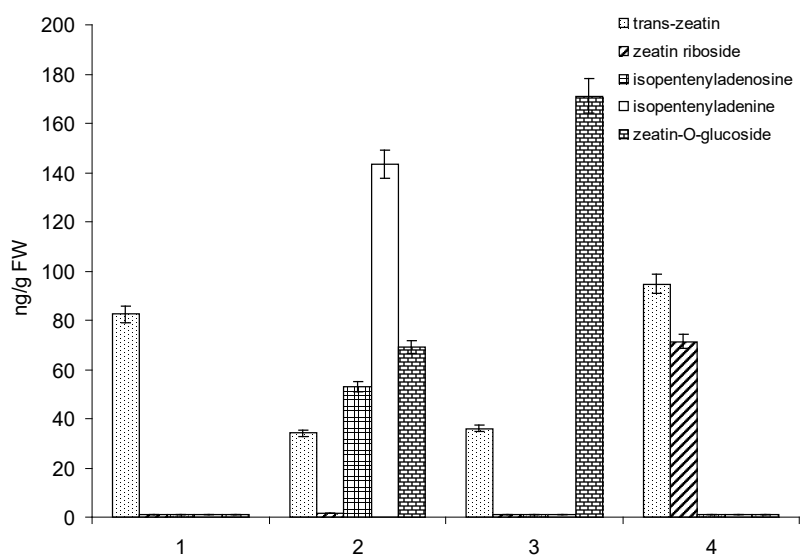

Fig. 4. Cytokinins content in rhizomes of the fern Polystichum aculeatum at different stages of the sporophyte development: 1 - stage of intensive vegetative growth, 2 - stage of sporangia formation, $3-$ stage of sporulation, $4-$ stage of winter vegetation

in which significant levels of cytokinins are found in fast-growing tissues with a high mitotic index (Schaller et al., 2014). It should be noted that the study of exogenous cytokinins effects on the growth of different fern species also gave contradictory results. Thus, the treatment with different cytokinins did not affect the growth of the M. quadrifolia stem (Rolli et al., 2015), whereas in Ceratopteris richardii Brongn. and Ceratopteris thalictroides (L.) Brongn. it led to the formation of callus tissue instead of new fronds and to the maintenance of the callus in a non-differentiated state (Plackett et al., 2014). Similarly, in M. quadrifolia, cytokinins inhibited the development of the rhizome 
(Rolli et al., 2015) while in Azolla filiculoides Lam., by contrast, they stimulated it (De Vries et al., 2016). Such discrepancies in data may be caused by the difference in the metabolism of cytokinins in various fern species.

In our experiments ferns sporophytes showed the occurrence of isopentenyl-type cytokinins at certain stages of the development. In D. filix-mas, low levels of isopentenyladenine were detected during sporulation, and in $P$. aculeatum, relatively high amounts of isopentenyladenosine and isopentenyladenine occurred in fronds at the stage of intensive growth and in rhizomes - during the sporangia formation. The most common and dominant cytokinin in flowering plants is known to be zeatin, whereas the concentration of isopentenyl-type forms in tissues is considerably lower, in many cases they are defined as a minor component of the cytokinin pool (Osugi, Sakakibara, 2015). In the lower plants, and especially in microorganisms, their quantity was quite high, therefore they were assumed to be active cytokinins in evolutionarily less developed organisms (Mok, Mok, 2001). Some increase in the concentration of isopentenyl-type forms in $D$. filixmas and $P$. aculeatum indicates the significance of these hormone forms in the regulation of certain aspects of growth and reproduction, and reflects the features of cytokinin metabolism in ferns that occupy an intermediate position in the evolutionary development between lower cryptogams and seed plants.

It should be noted that both species of ferns we studied, had the lower content of cytokinins in rhizomes compared to that in fronds, while in flowering plants, roots usually contain more cytokinins than the aerial part (Aloni et al., 2006). Differences of cytokinins distribution in shoot and root meristems of fern $A$. filiculoides were shown earlier, where hormone translocation pattern was different to that described in seed plants (Chiappetta, Innocenti, 2006). It is known that ferns, in contrast to flowering plants, do not form either a bipolar embryo, or a permanent germinal primary root, but form an adventitious root system. The fern root system is assumed to evolve from shoot meristems (Schneider, 2013). This is confirmed by the data on the stimulating effect of cytokinins on the development of root meristem in the fern A. filiculoides (De Vries et al., 2016), while in seed plants cytokinins are root growth inhibitors (Ivanov, Filin, 2017) and positive regulators of shoot apical meristem development (Kyozuka, 2017). Our findings regarding the distribution of cytokinins between the aerial and underground parts of the D. filix-mas and P. aculeatum sporophytes give evidence in favor of the idea of the evolutionary origin of the fern rhizome from the shoot tissues.

The common feature of $D$. filix-mas and $P$. aculeatum was the accumulation of zeatin- $O$-glucoside at the end of growth that is characteristic of most species of higher plants (Jameson, Song, 2016). $O$-glucosides of cytokinins are normally considered as stored inactive, but yet mobile forms that are readily hydrolyzed with $\beta$-glucosidase to active free molecules of the hormone. Such a pathway for cytokinins conjugation is aimed at protecting the $\mathrm{N}^{6}$-side chain from cleavage with cytokinin oxidase (Mok, Mok, 2001) and serves to inactivate hormones excess. In evolutionarily ancient organisms (algae, mosses, fungi), the formation of glucosides in the cytokinin metabolism is absent or very rare, and cytokinins homeostasis is maintained through the synthesis of inactive cis-forms (Záveská Drábková et al., 2015). However, $O$-glucosides of $c i s-$ and trans-zeatin riboside were among the most abundant intracellular cytokinins in bryophyte Physcomitrella patens (Hedw.) B.S.G. (Von Schwartzenberg et al., 2007). This finding together with our results about zeatin- $O$-glucoside concentration increase in ferns tissues with low growth intensity indicate that transformations of cytokinins, in particular, conjugation, in higher cryptogamous and flowering plants are similar, and that there is divergence in the metabolic pathways of these hormones in ferns and evolutionarily less developed organisms.

The main biological difference between the studied species of ferns is that in P. aculeatum, the aerial part of the plant does not die off, but remains green in winter. As our studies have shown, despite the fact that growth processes did not occur, and the general metabolism at a lower temperature significantly slowed down, the tissues maintained a sufficiently high level of active cytokinins. In fronds and rhizomes of this fern high levels of endogenous abscisic acid were found during the winter vegetation (Voytenko, Kosakivska, 2017), which probably compensate for the presence of cytokinins, restraining their growth-stimulating effect. It should be noted that it was during the winter vegetation when the maximum content of photosynthetic pigments (chlorophylls $a$ and $b$ and carotenoids) was detected in P. aculeatum (Shcherbatiuk et al., 2017). Previously, the ability of cytokinins to control the accumulation of chlorophyll and to regulate the activity of genes responsible for the stability of the ratio of $a / b$ chlorophylls was demonstrated in rice seedlings (Talla et al., 2016). A positive influence of cytokinins on the

Ukr. Bot. J., 2018, 75(4) 
maintenance of chlorophyll and senescence delay were also found in cryptogams, in particular in moss Bryum argenteum Hedw. (Sabovljevic et al., 2010). Cytokinins are known to stimulate photosynthesis at different levels of the cellular organization (regulation of chloroplast biogenesis, stimulation of chlorophyll and carotenoids synthesis, activation of photosynthesis, etc.) (Cortleven, Schmülling, 2015). It suggests that the function of cytokinins in fronds of $P$. aculeatum in the winter period is to maintain a certain level of photosynthetic pigments and photosynthetic activity under adverse conditions. Consequently, in ferns cytokinins appear to control not only growth and reproduction, but are also involved in the regulation of pigment composition and photosynthesis. Hence, the polyfunctionality, inherent in hormones of seed plants, manifested itself in vascular cryptogams as well.

\section{Conclusions}

Analysis of cytokinins in rhizomes and fronds of $D$. filix-mas and $P$. aculeatum revealed the speciesspecific quality composition and dynamics of individual forms of the hormone during the development of sporophytes. Accumulation of zeatin riboside in D. filix-mas sporophytes at reproductive stage and increase in trans-zeatin and zeatin riboside content during intensive vegetative growth of $P$. aculeatum were demonstrated. The common feature of both fern species and seed plants is accumulation of zeatin- $O$ glucoside as growth slows down. Unlike flowering plants, the root system of ferns was characterized by a lower level of cytokinins compared to that of the aerial part of plants. The accumulation of the hormone active forms in $P$. aculeatum in the winter period indicates the involvement of these hormones in the regulation of not only growth but also photosynthetic processes.

\section{REFERENCES}

Abul Y., Menéndez V., Gómez-Campo C., Revilla M.A., Lafont F. Occurrence of plant growth regulators in Psilotum nudum. J. Plant Physiology, 2010, 167(14): 12111213. https://doi.org/10.1016/j.jplph.2010.03.015

Aloni R., Aloni E., Langhans M., Ullrich C.I. Role of cytokinin and auxin in shaping root architecture: Regulating vascular differentiation, lateral root initiation, root apical dominance and root gravitropism. Ann. Bot., 2006, 97: 883-893. https://doi.org/10.1093/aob/mc1027

Babenko L.M., Skaterna T.D., Kosakivska I.V. Lipoxygenase activity in ontogenesis of ferns Salvinia natans and Polystichum aculeatum. Ukr. Biochem. J., 2017, 89(4): 5-12. https://doi.org/10.15407/ubj89.04.005

Babenko L.M., Romanenko K.O., Shcherbatiuk M.M., Vasheka O.V., Romanenko P.O., Negretsky V.A.,
Kosakivska I.V. Effects of exogenous phytohormones on spore germination and morphogenesis of Polystichum aculeatum (L.) Roth gametophyte in vitro culture. Cytology and Genetics, 2018, 52(2): 117-126. https://doi. org/10.3103/S0095452718020032

Bonomo M.C., Martinez O.G., Tanco M.E., Cardozo R., Aviles Z. Spores germination and gametophytes of Alsophila odonelliana (Cyatheaceae) in different sterile media. Phyton (B. Aires), 2013, 83(1): 119-126.

Chiappetta A., Innocenti A.M. Immunocytochemical localization of cytokinin in Azolla filiculoides. Plant Biosystems, 2006, 3: 229-233. doi.org/10.1080/11263500600756736.

Cortleven A., Schmülling T. Regulation of chloroplast development and function by cytokinin. J. Exp. Bot., 2015, 66(16): 4999-5013. https://doi.org/10.1093/jxb/ erv132

De Vries J., Fischer A.M., Roettger M., Rommel S., Schluepmann H., Brautigam A., Carlsbbecker A., Gould S.B. Cytokinin-induced promotion of root meristem size in the fern Azolla supports a shoot-like origin of euphyllophyte roots. New Phytologist, 2016, 209(2): 705-720. https://doi.org/10.1111/nph.13630

Greer G.K., Dietrich M.A., De Vol J.A., Rebert A. The effects of exogenous cytokinin on the morphology and gender expression of Osmunda regalis gametophytes. Amer. Fern J., 2012, 102(1): 32-46. https://doi. org/10.1640/0002-8444-102.1.32

Jameson P.E., Song J. Cytokinin: a key driver of seed yield. J. Exp. Bot., 2016, 67(3): 593-606. https://doi. org/10.1093/jxb/erv461

Ivanov V.B., Filin A.N. Cytokinins regulate root growth through its action on meristematic cell proliferation but not on the transition to differentiation. Functional Plant Biology, 2017, 45(2): 215-221. https://doi.org/10.1071/ FP16340

Kieber J.J., Schaller G.E. Cytokinins. The Arabidopsis Book, 2014, 11: e0168. https://doi.org/10.1199/tab.0168

Kosakivska I.V., Babenko L.M., Shcherbatiuk M.M., Vedenicheva N.P. Voytenko L.V., Vasyuk V.A. Phytohormones during growth and development of Polypodiophyta. Advances in Biology \& Earth Sciences, 2016, 1(1): 26-44.

Kotukhov Yu.A. Bull. Main Bot. Gard., 1974, 94: 10-18. [Котухов Ю.А. Методика фенонаблюдений за папоротниками семейства Polypodiaceae R. Br. Бюл. Глав. бот. сада, 1974, 94: 10-18].

Kyozuka J. Control of shoot and root meristem function by cytokinin. Curr. Opin. Plant Biol., 2007, 10: 442-446. https://doi.org/10.1016/j.pbi.2007.08.010

Mok D.W.S., Mok M.C. Cytokinin metabolism and action. Annu. Rev. Plant Physiol. Plant Mol. Biol., 2001, 52: 89118. doi: 10.1146/annurev.arplant.52.1.89.

Menéndez V., Revilla M.A., Fal M.A., Fenández H. The effect of cytokinins on growth and sexual organ development in the gametophyte of Blechnum spicant L. Plant Cell Tiss. Organ Cult., 2009, 96: 245-250. https:// doi.org/10.1007/s11240-008-9481-y

Menéndez V., Abul Y., Bohanec B., Lafont F., Fernández H. The effect of exogenous and endogenous phytohormones on the in vitro development of gametophyte and sporophyte in Asplenium nidus L. Acta Physiolo- 
giae Plantarum, 2011, 33(6): 2493-2500. https://doi. org/10.1007/s11738-011-0794-9

Osugi A., Sakakibara H. How do plants respond to cytokinins and what is their importance? BMC Biology, 2015, 13: 102. https://doi.org/10/1186/s12915-015-0214-5

Plackett A.R.G., Huang L., Sanders H.L., Langdale J.A. High-efficiency stable transformation of the model fern species Ceratopteris richardii via microparticle bombardment. Plant Physiol., 2014, 165(1): 3-14. https://doi. org/10.1104/pp.113.231357

Pryer K.M., Schneider H., Smith A.R., Cranfill R., Wolf P.G., Hunt J.S., Sipes S.D. Horstails and ferns are a monophyletic group and the closest living relatives to seed plants. Nature, 2001, 409(6820): 618-622. https://doi.org/10.1038/35054555

Rivera A., Conde P., Cañal M.J., Fernández H. Biotechnology and Apogamy in Dryopteris affinis spp. affinis: The Influence of Tissue Homogenization, Auxins, Cytokinins, Gibberellic Acid, and Polyamines. In: Current Advances in Fern Research. Ed. H. Fernández. Cham: Springer, 2018, pp. 139-152. https://doi.org/10.1007/978-3-319-75103-0_7

Rolli E., Brunoni F., Marieschi M., Torelli A., Ricci A. In vitro micropropagation of the aquatic fern Marsilea quadrifolia L. and genetic stability assessment by RAPD markers. Plant Biosystems, 2015, 149(1): 7-14. https:// doi.org/10.1080/11263504.2013.806366

Romanov G.A. How do cytokinins affect the cell? Russian J. Plant Physiol., 2009, 56(2): 268-290. https:// doi.org/10.1134/S1021443709020174

Sabovljević A., Soković M., Glamočlija J., Ćirić A., Vujićić M., Pejin B., Sabovljević M. Comparison of extract bio-activities of in situ and in vitro growth selected bryophyte species. Afr. J. Microbiol. Res., 2010, 4(9): 808-812.

Schaller G.E., Street I.H., Kieber J.J. Cytokinin and the cell cycle. Curr. Opin. Plant Biol., 2014, 21: 7-15. https://doi.org/10.1016/j.pbi.2014.05.015

Shcherbatiuk M.M., Babenko L.M., Vasheka O.V., Kosakivska I.V. Pigments and ultrastructural peculiaries of cell organells of fern Polystichum aculeatum (L.) Roth. at different stages of development. Biol. Stud., 2017, 11(2): 91-102. [Щербатюк М.М., Бабенко Л.М., Вашека О.В., Косаківська І.В. Пігменти й ультраструктурні особливості клітинних органел папороті Polystichum aculeatum (L.) Roth. у різні фази розвитку. Biol. Stud., 2017, 11(2): 91-102. https:// doi.org/10.30970/sbi.1102.526

Schneider H. Evolutionary morphology of ferns (monilophytes). Annual Plant Reviews, 2013, 45: 115-140. https://doi.org/10.1002/9781118305881.ch.4

Spiro M.D., Torabi B., Cornell C.N. Cytokinins induce photomorphogenic development in dark-grown gametophytes of Ceratopteris richardii. Plant Cell Physiol., 2004, 45(9): 1252-1260. https://doi.org/10.1093/pcp/pch146

Talla S.K., Panigrahy M., Kappara S., Nirosha P., Neelamraju S., Ramanan R. Cytokinin delays darkinduced senescence in rice by maintaining the chlorophyll cycle and photosynthetic complexes. J. Exp. Bot., 2016, 67(6): 1839-1851. https://doi.org/10.1093/jxb/erv575

Vasheka E.V. The some biological characteristics of ferns of genus Dryopteris Adans introduced into open ground in the Acad. O.V. Fomin Botanical Garden. Bull. Nikit. State Bot. Gard., 2004, 89: 12-15. [Вашека О.В. Деякі біоло- гічні особливості інтродукованих у відкритий грунт Ботанічного саду ім. акад. О.В. Фоміна папоротей роду Dryopteris Adans. Бюл. держ. Нікітськ. бот. садy, 2004, 89: 12-15].

Vedenicheva N.P., Musatenko L.I. Visn. Kharkiv. nats. agrar. un-tu. Ser. Biology, 2008, 3(15): 15-23. [Веденичова Н.П., Мусатенко Л.І. Участь цитокінінів у формуванні репродуктивних органів рослин з різним типом росту. Вісн. Харків. нац. аграрн. ун-ту. Сер. Біологія, 2008, 3(15): 15-23].

Vedenicheva N.P., Sytnik K.M. Cytokinins localization and dynamics in different parts of Equisetum arvense L. Dop. Nac. akad. nauk Ukr., 2013, 11: 150-156. [Веденичова Н.П., Ситник К.М. Локалізація і динаміка цитокінінів у різних частинах рослин Equisetum arvense L. Доп. НАН України, 2013, 11: 150-156].

Vedenicheva N.P. Visn. Kharkiv. nats. agrar. un-tu. Ser. Biology, 2016, 1(37): 6-26. [Веденичова Н.П. Цитокініни як регулятори росту органів рослин за різних умов існування. Вісн. Харків. нац. аграр. ун-ту. Сер. Біологія, 2016, 1(37): 6-26].

Vedenicheva N.P., Kosakivska I.V. Ukr. Bot. J., 2016, 72(3): 277-282. [Веденичова Н.П., Косаківська І.В. Ендогенні цитокініни водної папороті Salvinia natans (Salviniaceаe). Укр. бот. журн., 2016, 72(3): 277-282]. https://doi.org/ 10.15407/ukrbotj73.03.277

Vedenicheva N.P., Al-Maali G.A., Mytropolska N.Yu., Mykhaylova O.B., Bisko N.A., Kosakivska I.V. Endogenous cytokinins in medicinal basidiomycetes mycelial biomass. Biotechnologia Acta, 2016, 9(1): 55-63. https:// doi.org/10.15407/biotech9.01.055

Vedenicheva N.P., Kosakivska I.V. Cytokinins as regulators of plant ontogenesis under different growth conditions. Kyiv: Nash Format, 2017, 200 pp. [Веденичова Н.П., Косаківська І.В. Цитокініни як регулятори онтогенезу рослин за різних умов зростання. Київ: Наш формат, 2017, 200 c.].

Von Schwartzenberg K., Fernández Núñez M., Blaschke H., Dobrev P.I., Novák O., Motyka V., Strnad M. Cytokinins in the bryophyte Physcomitrella patens: analyses of activity, distribution, and cytokinin oxidase/dehydrogenase overexpression reveal the role of extracellular cytokinins. Plant Physiol., 2007, 145(3): 786-800. https://doi.org/ 10.1104/pp.107.103176

Voytenko L.V., Kosakivska I.V. Dopov. Nac akad. nauk Ukr., 2017, 12: 112-118. [Войтенко Л.В., Косаківська I.В. Особливості акумуляції та розподілу індоліл-3-оцтової та абсцизової кислот в органах спорофіта дикорослої папороті Polystichum aculeatum (L.) Roth на різних фенологічних фазах розвитку. Доп. НАН України, 2017, 12: 112-118.

Záveská Drábková L., Dobrev P.I., Motyka V. Phytohormone profiling across the Bryophytes. PLoS ONE, 2015, 10(5): e0125411. https://doi.org/10.1371/journal. pone. 0125411

Zürcher E., Müller B. Cytokinin synthesis, signaling and function - advances and new insights. Int. Rev. Cell Mol. Biol., 2016, 324: 1-38. https://doi.org/10.1016/ bs.ircmb.2016.01.001.

Recommended for publication by O.K. Zolotareva
Submitted 26.06.2018

Ukr. Bot. J., 2018, 75(4) 
Веденичова Н.П., Косаківська І.В. Динаміка ендогенних цитокінінів упродовж розвитку спорофітів папоротей Dryopteris filix-mas і Polystichum aculeatum (Dryopteridaceae). Укр. бот. журн., 2018, 75(4): 384-391. Інститут ботаніки ім. М.Г. Холодного НАН України вул. Терещенківська, 2, Київ 01004, Україна

Якісний склад i динаміку цитокінінів у ваях i
кореневищах багаторічних папоротей filix-mas i Polystichum aculeatum досліджено методом високоефективної рідинної хроматографії у поєднанні 3 мас-спектрометрією. Спорофіти вивчали на стадіях інтенсивного вегетативного росту (квітень), формування спорангіїв (травень) і спороношення (червень). Рослини $P$. aculeatum аналізували також на стадії зимової вегетації (лютий). Виявлено накопичення транс-зеатину у ваях $P$. aculeatum на стадії інтенсивного росту, тоді як у D. filix-mas зростання вмісту цього цитокініну спостерігалося в період формування спорангіїв. У обох видів папоротей на стадії спороношення у ваях і кореневищах зростав рівень зеатинрибозиду. Припинення інтенсивного росту папоротей супроводжувалося накопиченням кон'югату - зеатин$O$-глюкозиду. На певних стадіях розвитку спорофітів було знайдено ізопентенільні форми цитокінінів: у D. filix-mas невисокі рівні ізопентеніладеніну - в період спороношення, а в P. aculeatum - досить значні кількості ізопентеніладенозину й ізопентеніладеніну у ваях на стадії інтенсивного росту й в кореневищах - під час формування спорангіїв. У ваях $P$. aculeatum у період зимової вегетації акумулювалися активні вільні форми цитокінінів - транс-зеатин і зеатинрибозид, що вказує на їхню участь у підтримці фотосинтетичної активності рослини за несприятливих умов. Коренева система обох видів папоротей характеризувалася більш низьким рівнем цитокінінів, ніж надземна частина рослин. Динаміка спектру й вмісту цитокінінів в органах папоротей мала видоспецифічний характер, що опосередковано свідчило про участь цих фітогормонів у контролюванні процесів росту й розвитку. Обговорено риси відмінності й подібності регуляторної ролі цитокінінів у папоротей та квіткових рослин.

Ключові слова: Polystichum aculeatum, Dryopteris filix-mas, цитокініни, папороті, ріст, розвиток
Веденичева Н.П., Косаковская И.В. Динамика эндогенных цитокининов в ходе развития спорофитов папоротников Dryopteris filix-mas и Polystichum aculeatum (Dryopteridaceae). Укр. бот. журн., 2018, 75(4): 384-391.

Институт ботаники им. Н.Г. Холодного НАН Украины ул. Терещенковская, 2, Киев 01004, Украина

Качественный состав и динамику цитокининов в вайях и корневищах многолетних папоротников Dryopteris filix-mas и Polystichum aculeatum исследовали методом высокоэффективной жидкостной хроматографии в сочетании с масс-спектрометрией. Спорофиты изучали на стадиях интенсивного вегетативного роста (апрель), формирования спорангиев (май) и спороношения (июнь). Растения $P$. aculeatum анализировали также на стадии зимней вегетации (февраль). Обнаружено накопление транс-зеатина в вайях $P$. aculeatum на стадии интенсивного роста, тогда как у D. filix-mas возрастание содержания этого цитокинина наблюдалось в период формирования спорангиев. У обоих видов папоротников на стадии спороношения в вайях и корневищах возрастал уровень зеатинрибозида. Прекращение интенсивного роста папоротников сопровождалось накоплением конъюгата - зеатин$O$-глюкозида. На определенных стадиях развития спорофитов были выявлены изопентенильные формы цитокининов: у D. filix-mas невысокие уровни изопентениладенина - в период спороношения, а у $P$. aculeatum достаточно значительные количества изопентениладенозина и изопентениладенина - в вайях на стадии интенсивного роста и в корневищах - во время формирования спорангиев. В вайях $P$. aculeatum в период зимней вегетации аккумулировались активные свободные формы цитокининов - трансзеатин и зеатинрибозид, что указывает на их участие в поддержании фотосинтетической активности растений в неблагоприятных условиях. Корневая система обоих видов папоротников характеризовалась более низким уровнем цитокининов, чем надземная часть растений. Динамика спектра и содержания цитокининов в органах папоротников имела видоспецифический характер, что и косвенно свидетельствовало об участии этих фитогормонов в контроле процессов роста и развития. Обсуждаются черты различия и сходства регуляторной роли цитокининов у папоротников и цветковых растений.

Ключевые слова: Polystichum aculeatum, Dryopteris filixmas, цитокинины, папоротники, рост, развитие 